\title{
HARTA BERSAMA DAN KEDUDUKAN ANAK DALAM RUMAH TANGGA TKW YANG BERCERAI DARI PERKAWINAN SIRRI DI DESA BUNDER
}

\author{
Abdul Wahid \\ Fakultas Hukum Universitas Muhammadiyah Cirebon \\ Jalan Tuparev Nomor 70 Cirebon \\ Email : abdulwahid.lawyercrb@gmail.com
}

\begin{abstract}
ABSTRAK
Hidup bersama antara seorang pria dan seorang wanita mempunyai akibat yang sangat penting dalam masyarakat, baik terhadap kedua belah pihak maupun keturunannya serta anggota masyarakat yang lainnya. Oleh karena itu dibutuhkan suatu peraturan yang mengatur tentang hidup bersama antara lain syarat-syarat untuk peresmian hidup bersama, pelaksanaannya, kelanjutannya dan berakhirnya perkawinan itu. Undang-undang Nomor 1 tahun 1974 tentang Perkawinan, merupakan salah satu wujud aturan tata tertib pernikahan yang dimiliki oleh negara Indonesia sebagai bangsa yang berdaulat, di samping aturanaturan tata tertib pernikahan yang lain yaitu Hukum Adat dan Hukum Agama.

Agar terjaminnya ketertiban pranata pernikahan dalam masyarakat, maka Undang-undang Nomor 1 Tahun 1974 jo. Peraturan Pemerintah Nomor 9 Tahun 1975 menentukan bahwa setiap perkawinan harus dicatat oleh petugas yang berwenang. Namun kenyataan memperlihatkan fenomena yang berbeda. Hal ini tampak dari maraknya pernikahan siri atau pernikahan di bawah tangan rumah tangga TKW yang terjadi di Desa Bunder Susukan Cirebon.
\end{abstract}

Kata Kunci : Harta Bersama, Anak, Cerai, Perkawinan Sirri

\begin{abstract}
Living together between a man and a woman has a very important consequence in society, both to both parties and their descendants and other members of society. Therefore, a regulation that regulates coexistence is required for the inauguration of the collective life, its implementation, the continuation and the end of the marriage. Act No. 1 of 1974 concerning Marriage, is one form of marriage rule rules owned by the state of Indonesia as a sovereign nation, in addition to other rules of marriage discipline namely Customary Law and Religious Law.

In order to ensure the order of marriage institutions in society, Law No. 1 of 1974 jo. Government Regulation No. 9 of 1975 stipulates that every marriage should be recorded by authorized officers. But reality shows different phenomena. This is evident from the rise of siri or marriage marriage under the hands of household TKW that occurred in the village Bunder Susukan Cirebon.
\end{abstract}

Keywords: Joint Treasure, Child, Divorce, Sirri Marriage 


\section{A. PENDAHULUAN}

\section{Latar Belakang}

Indonesia sebagai salah satu negara yang memiliki populasi umat Islam terbesar di dunia tentu juga mengatur tentang pernikahan atau perkawinan yang tertuang di dalam Undang-undang Nomor 1 tahun 1974 tentang Perkawinan dan Kompilasi Hukum Islam tentang Perkawinan. Jika yang pertama merupakan norma hukum yang berlaku mengikat untuk semua Warga Negara Indonesia (WNI) dimana pun berada. Maka yang kedua secara yuridis hanya mengikat Warga Negara Indonesia yang beragama Islam semata.

$$
\text { Pada }
$$

prinsipnya perkawinan adalah suatu akad, untuk menghalalkan hubungan serta membatasi hak dan kewajiban, tolong menolong antara pria dengan wanita yang antara keduanya bukan muhrim. Apabila di tinjau dari segi hukum, jelas bahwa pernikahan adalah suatu akad yang suci dan luhur antara pria dengan wanita, yang menjadi sebab sahnya status sebagai suami isteri dan dihalalkan hubungan seksual dengan tujuan mencapai keluarga sakinah, mawadah serta saling menyantuni antara keduanya.

Suatu akad perkawinan menurut Hukum Islam ada yang sah ada yang tidak sah. Hal ini dikarenakan, akad yang sah adalah akad yang dilaksanakan dengan syarat-syarat dan rukunrukun yang lengkap, sesuai dengan ketentuan agama. Sebaliknya akad yang tidak sah, adalah akad yang dilaksanakan tidak sesuai dengan syarat-syarat serta rukun-rukun perkawinan.
Akan tetapi pada kenyataan di Desa Bunder ada fenomena perkawinan yang dilakukan hanya dengan Hukum Agamanya saja khususnya dalam rumah tangga TKW. Perkawinan ini sering disebut Perkawinan Siri, yaitu perkawinan yang tidak terdapat bukti otentik, sehingga tidak mempunyai kekuatan hukum.

Pernkawinan sirri yang terjadi di Desa Bunder dilakukan karena berbagai alasan. Mulai dari alasan ekonomi, sosial, perbedaan pemahaman serta masih banyak alasan lainnya. Hal inilah yang penyebab terjadinya konflik rumah tangga apabila tidak dapat mempertahankan eksistensi perkawinan sirri dan menjamin serta melindungi ikatan perkawinan tersebut serta akibat hukum lain yang mungkin timbul dikemudian hari khususnya perselesihan terkait dengan pembagian harta bersama dalam rumah tangga yang bercerai dikalangan rumah tangga TKW di Desa Bunder.

\section{Kerangka Teori}

Teori yang digunakan dalam penelitian ini adalah teori fungsionalisme struktural yang dikenalkan oleh Talcott Parson, yaitu memandang realitas sosial sebagai hubungan sistem: sistem masyarakat, yang berada dalam keseimbangan, yakni kesatuan yang terdiri dari bagian-bagian yang saling tergantung, sehingga perubahan satu bagian dipandang menyebabkan perubahan lain dari sistem. ${ }^{1}$

Teori fungsionalisme struktural Parsons berkonsentrasi pada struktur masyarakat dan

\footnotetext{
${ }^{1}$ George Ritzer - Douglas J. Goodman , Teori Sosiologi Modern; edisi ke -6 ( Jakarta: Kencana Prenada Media Group, 2011), 117.
} 
antar hubungan berbagai struktur tersebut yang dilihat saling mendukung menuju keseimbangan dinamis.

III. Penelitian Sebelumnya

Berdasarkan hasil penelusuran, Peneliti mendapat pada penelitian dalam bentuk tesis yang ditulis oleh Yunthia Misliranti, pada program studi Magister Kenotariatan dengan judul : "Kedudukan Dan Bagian Isteri Atas Harta Bersama Bagi Isteri Yang Dicerai Dari Pernikahan Sirri" yang mengungkapkan tiga dua pokok permasalahan yaitu bagaimanakah pengaturan harta bersama dalam hal terjadi perceraian dari Perkawinan sirri(bawah tangan) dan bagaimanakah kedudukan dan bagian isteri atas harta bersama bagi isteri yang dicerai dari pernikahan sirri.

Perbedaan penelitian yang diusulkan oleh Peneliti dengan penelitian yang disebutkan diatas terdapat perbedaan dari substansi subjek dan objek penelitiannya serta tempat penelitiannya : "Harta Bersama dan Kedudukan Anak Dalam Rumah Tangga TKW Yang Bercerai Dari Perkawinan Sirri Di Desa Bunder" yang mengungkapkan dua pokok permasalahan yaitu bagaimana pembagian harta bersama rumah tangga TKW yang bercerai dari perkawinan sirri dan bagaimana kedudukan anak dalam rumah tangga TKW yang bercerai dari perkawinan sirri.

Penelitian yang diusulkan oleh Peneliti lebih menarik dari penelitian sebelumnya, karena subjek penelitian ini terkhusus rumah tangga TKW yang mana pihak isteri bekerja di luar negeri menjadi tulang punggung keluarga yang seharusnya menjadi kewajiban dan tanggung jawab seorang suami. Adapun tujuan dari penelitian ini untuk mengetahui pembagian harta bersama rumah tangga TKW yang bercerai dari perkawinan sirri dan mengetahui kedudukan anak dalam rumah tangga TKW yang bercerai dari perkawinan sirri di Desa Bunder.

\section{B. METODE PENELITIAN}

Penelitian ini menggunakan metode penelitian dengan pendekatan yuridis sosiologis (social legal approach). Pendekatan yuridis sosiologis dimaksudkan sebagai penerapan dan pengkajian hubungan aspek hukum dengan aspek non hukum dalam bekerjanya hukum di masyarakat. Penelitian hukum yang sosiologis mengikuti pola penelitian ilmu-ilmu sosial khususnya sosiologi sehingga penelitian ini disebut socio legal research. Penelitian hukum sosiologis atau empiris hendak mengadakan pengukuran terhadap peraturan perundang-undangan tertentu mengenai efektivitasnya, maka definisi-definisi operasional dapat diambil dari peraturan perundangundangan tersebut. ${ }^{2}$ Sedangkan menurut Abdul Kadir Muhammad bahwa penelitian hukum socio legal adalah mengkaji pelaksanaan atau implementasi ketentuan hukum positif (perundangundangan) dan kontrak secara aktual pada setiap peristiwa hukum tertentu yang terjadi dalam masyarakat guna mencapai tujuan yang telah ditentukan. ${ }^{3}$

Spesifikasi penelitian ini menggunakan tipe deskriptif analitis yaitu penelitian yang disamping memberikan gambaran, menuliskan

\footnotetext{
${ }^{2}$ Soerjono Soekanto, Pengantar Penelitian Hukum, (Jakarta: UI Press, 2010), 53.

3 Abdulkdir Muhammad, Hukum dan Penelitian Hukum, (Bandung: Citra Aditya Bakti, 2004),134.
} 
dan melaporkan suatu obyek atau suatu peristiwa juga akan mengambil kesimpulan umum dari masalah yang dibahas yaitu terkait pembagian harta bersama dalam rumah tangga TKW yang bercerai dari perkawinan sirri di Desa Bunder.

Jenis penelitian ini menggunakan penelitian deskriptif analitis adalah penelitian yang dimaksudkan untuk mengumpulkan informasi mengenai status gejala yang ada, yaitu gejala keadaan yang apa adanya pada saat penelitian dilakukan. Penelitian deskriptif analitis juga merupakan gambaran yang bersifat sistematik, faktual dan akurat mengenai fakta-fakta serta ciri khas tertentu yang terdapat dalam suatu objek penelitian. Dengan kata lain peneliti dapat mendeskripsikan suatu gejala, peristiwa, dan kejadian yang terjadi pada saat dilapangan. Dengan itu Peneliti menggunakan bahan hukum primer, sekunder dan tersier. ${ }^{4}$

Metode analisis data dalam penelitian ini menggunakan analisis data secara kualitatif, yaitu analisis yang dilakukan dengan memahami dan merangkai data yang telah diperoleh dan disusun sistematis, kemudian ditarik kesimpulan. Dan kesimpulan yang diambil dengan menggunakan cara berpikir deduktif, yaitu dengan cara berpikir yang mendasar pada hal-hal yang bersifat umum kemudian ditarik kesimpulan secara khusus.

\section{HASIL DAN PEMBAHASAN}

\section{Harta Bersama Dalam Rumah Tangga TKW di Desa Bunder}

Peneliti menemukan bahwa di Desa Bunder Kecamatan Susukan Kabupaten Cirebon masih banyak masyarakat Desa Bunder yang

\footnotetext{
${ }^{4}$ Suharsimi Arikunto,Manajemen Penelitian, (Jakarta: Rineka Citra, 2005), 45.
}

melaksanakan perkawinan sirri. Ada beberapa alasan yang melatar belakangi pernikahan tersebut mereka laksanakan sebagai berikut:

\begin{tabular}{llr}
\multicolumn{1}{c}{ Pertama, } & di & dalam \\
masyarakat & yang & tidak \\
membolehkan & budaya & seks
\end{tabular} bebas (free sex) dan kumpul kebo seperti di negara Indonesia ini, maka pernikahan adalah lembaga yang memiliki fungsi paling pokok dan legal untuk memenuhi kebutuhan ini. Didalamnya tersirat pengertian bahwa dengan menikah secara sirri berarti perbuatan yang semula dianggap dosa dan mengakibatkan perasaan bersalah itu berubah statusnya menjadi tindakan atau perbuatan yang sah dan boleh dalam agama.

Kedua, permintaan mereka dengan alasan ekonomi sehingga pernikahan itu secepatnya dilakukan dan cukup dilakukan secara agama Islam saja. Bahwa karena faktor ekonomi maka pernikahan secara agama Islam adalah pilihan terbaik dan lebih ekonomis, serta sangat membantu. Pernikahan secara agama islam cukup dilakukan dihadapan ulama atau kiai sebagai penghulu nikahnya. Undang-Undang

Perkawinan Nomor 1 Tahun 1974 tentang Perkawinan menyebutkan bahwa setiap perkawinan harus dicatat. Dalam masyarakat Indonesia salah satu bentuk perkawinan yang dikenal yang disembunyikan adalah nikah sirri. Nikah sirri adalah nikah yang dilakukan secara sembunyi-sembunyi, ada yang dicatat tapi disembunyikan dari masyarakat dan ada juga yang tidak dicatatkan pada Petugas Pencatat Nikah (PPN) dan tidak 
terdaftar di Kantor Urusan Agama (KUA). Nikah sirri lazim disebut juga dengan nikah di bawah tangan. ${ }^{5}$

Perkawinan yang dilakukan oleh suami isteri secara sah akan membawa konsekuensi dan akibat dang hukum. Akibat hukum tersebut adalah : ${ }^{6}$

a. Timbulnya hubungan antara suami isteri. Dalam hubungannya sebagai suami isteri dalam perkawinan yang sah, maka mereka mempunyai hak dan kewajiban yang harus dilaksanakan untuk menegakkan rumah tangganya.

b. Timbulnya harta benda dalam perkawinan. Suami isteri yang terikat dalam perkawinan yang sah, akan mempunyai harta benda, baik yang diperoleh sebelum perkawinan maupun selama perkawinan. Pengaturan terhadap harta kekayaan perkawinan tersebut selanjutnya diatur pada Pasal 35 sampai Pasal 37 Undang - Undang Perkawinan No. 1 Tahun 1974.

c. Timbulnya hubungan antara orang tua dan anak Akibat hukum terakhir dari perkawinan yang sah adalah adanya hubungan antara orang tua dan anak.
Pengaturan selanjutnya terhadap hal ini diatur dalam Pasal 45 sampai Pasal 49 Undang Undang No. 1 Tahun 1974.

Akad nikah sirri dapat berakibat mempengaruhi kemaslahatan harta. Disebut demikian karena dengan tidak jelasnya identitas pernikahan dan pernikahan pun tidak dapat dibuktikan melalui buku nikah, maka identitas anak yang dilahirkan juga tidak jelas, sehingga ketika orang tuanya meninggal, anak mendapatkan kesulitan untuk mendapatkan harta waris dari orang tuanya, termasuk pula isteri akibat akad nikah sirri ini, dia pun mendapatkan kesulitan untuk menyatakan dirinya sebagai ahli waris yang sah, baik sebagai isteri pertama atau sebagai isteri yang kedua dan seterusnya. ${ }^{7}$

Di dalam Kamus Besar
Bahasa Indonesia istilah
perkawinan dimaknai sebagai
peristiwa maupun hasil dari
suatu peristiwa. Peristiwa dimana dua orang mengikat janji untuk hidup bersama. Dalam perspektif sosiologis, perkawinan yang merupakan ikatan lahir dan batin antara seorang laki-laki dengan seorang perempuan dalam suatu hubungan suami isteri ini diberikan kekuatan sanksi sosial. $^{8}$

Fenomena saat ini yang terjadi di Desa Bunder khususnya dalam rumah tangga

\footnotetext{
${ }^{5}$ Mardani, Hukum Perkawinan Islam di Dunia Islam Modern, (Yogjakarta: Graha Ilmu, 2011), hal. 17.

${ }^{6}$ Keputusan Fatwa Majelis Ulama Indonesia Nomor : 4/MUNAS VII/MUI/8/2005 tentang Perkawinan Beda Agama.
}

\footnotetext{
${ }^{7}$ Jurnal Ilmiah FENOMENA, Volume X, Nomor 2, November 2012: 982 - 998.

${ }^{8}$ Indriyani, Sri Sutanti, Sosiologi Suatu Kajian Hidup Bermasyarakat (Sukoharjo: Ghalia Indonesia, 2007), 44
} 
TKW dari perkawinan sirri yang mana pihak isteri bekerja ke luar negeri menghasilkan banyak harta benda dalam keluarga. Perkawinan yang berlandaskan sakinah, mawaddah dan rahmah kandas ditengah jalan, diakibatkan beberapa faktor:

a. Suami yang ditinggalkan di rumah melakukan hubungan dengan perempuan lain.

b. Suami atau isteri ingin menguasai seluruh harta yang dihasilkan selama perkawinan.

c. Isteri tidak menghormati dan melayani suami karena isteri yang merasa mempunyai harta dalam keluarga.

d. Adanya faktor lain ari pihak ketiga yang menjadi penyebab crai rumah tangga TKW dari perkawinan sirri.

Akibat dari perceraian tersebut berujung terjadi polemik dan perselisihan terkait pembagian harta bersama dalam rumah tangga TKW yang bercerai dari perkawinan sirri yang terjadi di Desa Bunder.

Apabila ditinjau dari sahnya perkawinan menurut Undang-Undang Nomor 1 Tahun 1974 ditentukan dalam Pasal 2 ayat (1) yang menentukan, bahwa; “ Perkawinan adalah sah apabila dilakukan menurut hukum masing-masing agamanya dan kepercayaannya itu." Dari ketentuan diatas dapat diketahui bahwa Undang-Undang Perkawinan menitik beratkan sahnya perkawinan pada dua unsur, yaitu; perkawinan harus dilaksanakan sesuai dengan syarat dan prosedur yang ditentukan oleh Undang-Undang (hukum negara) dan hukum agama. Artinya kalau perkawinan hanya dilangsungkan menurut ketentuan Undang-Undang negara tanpa memperhatian ketentuan-ketentuan agama perkawinan tersebut tidak sah, demikian juga sebaliknya. ${ }^{9}$

Maka konsekuensinya
harta benda yang selama diperoleh setelah perkawinan sirri baik didapatkan oleh suami maupun isteri tidak bisa diperhitungkan sebagai harta aktiva maupun pasiva dalam keluarga yang seharusnya ada pembagian harta bersama apabila terjadi perceraian. Apabila ini tetap diterapkan akan menimbulkan konflik rumah tangga sehingga tidak tercapainya azas kesamaan dihadapan hukum, keadilan, dan kepastian hukum.

Oleh karenanya, untuk menyelesaikan polemik dan perselihan tersebut di atas menggunakan teori fungsionalisme struktural yang dikenalkan oleh Talcott Parsons, bahwa perkawinan sebagai sebuah realitas sosial tentunya selalu terintegrasi dengan kehidupan masyarakatnya. Dalam Teori strukrural fungsional Parsons, dijelaskan bahwa masyarakat terintegrasi atas dasar kesepakatan dari para anggotanya akan nilai-nilai kemasyarakatan tertentu yang memiliki kemampuan mengatasi perbedaan-perbedaan sehingga masyarakat tersebut dipandang sebagai suatu sistem yang secara fungsional terintegrasi dalam suatu keseimbangan. Dengan demikian masyarakat adalah

\footnotetext{
${ }^{9}$ Wahyono Darmabrata, Tinjauan UU No. 1 Tahun 1974, (Gitama Jaya, Jakarta, 2003), . 101.
} 
merupakan kumpulan sistemsistem sosial yang satu sama lain berhubungan dan saling memiliki ketergantungan. Parsons kemudian mengembangkan apa yang disebut imperatif-imperatif fungsional, yang dikenal sebagai skema AGIL. Agar tetap bertahan (survive), suatu sistem harus memiliki empat fungsi yaitu: ${ }^{10}$

1. Adaptation: fungsi yang amat penting disini dimana sistem harus dapat beradaptasi dengan cara menanggulangi situasi eksternal yang gawat, dan sistem harus bisa menyesuaikan diri dengan lingkungan juga dapat menyesuaikan lingkungan untuk kebutuhannya.

2. Goal Attainment: pencapaian tujuan sangat penting., dimana sistem harus bisa mendefiniskan dan mencapai tujuan.

3. Integration : artinya sebuah sistem harus mampu mengatur dan menjaga antar hubungan bagian-bagian yang menjadi komponennya (termasuk aktor-aktornya), selain itu mengatur dan mengelola ketiga fungsi (AGIL) .

4. Latency: laten berarti sistem harus mampu berfungsi sebagai pemelihara pola, sebuah sistem harus memelihara dan memperbaiki motivasi pola-pola individu dan cultural.

\footnotetext{
${ }^{10}$ George Ritzer - Douglas J. Goodman, , 117.
}

Parsons secara khusus
tidak menyoroti tentang
perkawinan. Akan tetapi perlu
dipahami bahwa perkawinan
merupakan sebuah realitas sosial. Dan realitas sosial merupakan suatu sistem sosial. Dalam konteks perkawinan sirri yang terjadi di Desa Bunder, khususnya perkawinan dalam rumah tangga TKW masih berada dalam keteganganketegangan. Sistem yang ada belum begitu mampu mengatasi kebutuhan masyarakatnya. Padahal kenyataannya, kehidupan masyarakat sangat heterogen dan bersifat pluralistik. Dengan kenyataan seperti ini, maka seharusnya sistem sosial yang ada mampu mengatur setiap komponen dan elemen yang ada dalam sistem tersebut untuk mampu mencapai tujuannya.

Salah satu tujuan hidup bersama dalam negara demokrasi ini adalah seperti yang tertuang dalam Pasal 28D ayat 1 UUD 1945, yaitu: (1) Setiap orang berhak atas pengakuan, jaminan, perlindungan, dan kepastian hukum yang adil serta perlakuan yang sama dihadapan hukum. Berdasarkan pasal ini seharusnya sistem sosial yang ada mampu mengatasi dan mengatur kebutuhan masyarakatnya seperti kebutuhan atas penerimaan/pengakuan, kebutuhan akan adanya jaminan perlindungan, kebutuhan akan adanya kepastian hukum yang adil dan juga kebutuhan akan perlakuan yang sama.

Berkaitan dengan persoalan harta bersama dalam rumah tangga TKW yang bercerai dari perkawinan sirri, 
dalam kenyatannya nilai-nilai, Norma-norma atau aturan hukum yang berlaku tidak sepenuhnya mampu menjawab kebutuhan sosial masyarakatnya. Sehingga individu yang ada dalam sistem tersebut tentunya berusaha untuk mengatur dan mengatasinya dengan berbagai alternatif untuk menghubungkan dan menyesuaikan satu bagian dengan bagian lainnya. Apapun bentuknya dan produk-produk hukum terkait dengan pembagian harta bersama rumah tangga TKW yang bercerai dari perkawinan sirri di Desa Bunder dengan pembagian tidak menggunakan sistem bagi rata terhadap harta yang dihasilkan setelah pernikahannya, yaitu dengan kesepakatan sebagai berikut :

1. Apabila suami lebih banyak bekerja dibanding isteri, menghasilkan harta maka bagian suami sama besar dengan bagian isteri dihitung dari jumlah banyaknya aset dalam keluarga;

2. Apabila isteri lebih banyak bekerja dibanding suami, menghasilkan harta maka bagian isteri lebih besar dibanding bagiannya suami dihitung dari jumlah banyaknya aset dalam keluarga;

3. Apabila suami atau isteri bekerja mengahasilkan harta yang sama banyaknya maka bagian isteri lebih besar dibanding bagian suami.

Sistem pembagian harta bersama di atas di luar nafkah anak dan harta bawaan yang diperoleh suami atau isteri sebelum melaksanakan perkawinan sirri tidak menjadi bagian dari harta bersama. Sistem pembagian yang berlaku dikalangan masyarakat Desa Bunder ini lebih efektif dan adil yang tidak menimbulkan perselisian yang berkelanjutan serta pemberlakukan sistem ini substansinya untuk melindungi dan memberikan jaminan terhadap isteri dan anak.

II. Kedudukan Anak dari Perkawinan Sirri

Perintah untuk melakukan pencatatan setiap perkawinan adalah perintah yang bersifat wajib (imperatif), yang tujuannya antara lain untuk memperoleh legalitas dan pengakuan dari negara bahwa suatu perkawinan itu telah terjadi, sehingga semua akibat hukum dan hal-hal yang berkaitan dengan perkawinan tersebut dapat diselesaikan melalui lembaga resmi negara, yaitu lembaga peradilan. ${ }^{11}$

Suatu perkawinan yang mengabaikan perintah Pasal 2 ayat (2) UU Perkawinan tersebut akan berakibat hukum pada status perkawinan itu sendiri, yaitu dalam perspektif hukum positif di Indonesia tersebut dinyatakan tidak mempunyai kekuatan hukum (no legal force) sebagaimana bunyi Pasal 6 ayat (2) Kompilasi Hukum Islam, bahwa perkawinan yang dilakukan di luar pengawasan Pegawai Pencatat Nikah tidak mempunyai kekuatan hukum. Oleh karena itu, setiap perkawinan yang tidak dicatatkan pada Pegawai Pencatat Nikah, maka dinyatakan sebagai tidak pernah ada (never existed), dan akibat

\footnotetext{
${ }^{11}$ M. Anshary MK, Kedudukan Anak Dalam Perspektif Hukum Islam dan Hukum Nasional, (Bandung : CV Mandar Maju, 2014), . 133.
} 
labih jauh lagi bahwa perkawinan semacam itu tidak dilindungi hukum (no legal protect). ${ }^{12}$ Sehingga bila seorang anak yang dilahirkan itu memerlukan akta kelahiran untuk suatu kepentingan seperti persyaratan memasuki suatu perguruan (sekolah) misalnya, tidak mencantumkan nama bapaknya, karena orang tuanya tidak memiliki bukti tentang perkawinan berupa akta nikah, sebab dasar untuk menerbitkan akta kelahiran anak adalah akta nikah orang tuanya.

Hak asasi anak diperlakukan berbeda dari orang dewasa, karena anak sejak masih dalam kandungan, dilahirkan, tumbuh dan berkembang sampai menjadi orang dewasa, masih dalam keadaan tergantung, belum mandiri dan bahkan memerlukan perhatian/perlakuan khusus baik dalam gizi, kesehatan, pendidikan, pengetahuan, agama dan ketrampilan, pekerjaan, keamanan, bebas dari rasa takut, bebas dari rasa kekhawatiran maupun kesejahteraannya. Perlakuan khusus tersebut berupa mendapat perlindungan hukum dalam mendapatkan hak sipil, hak politik dan ekonomi, hak sosial maupun hak budaya yang lebih baik. ${ }^{13}$

Menurut Talcott Parsons dalam teorinya mengemukakan bahwa Integrasi sosial ini mengonseptualisasikan

masyarakat ideal yang di dalamnya nilai-nilai budaya diinstitusionalisasikan dalam sistem sosial, dan individu (sistem kepribadian) akan

\footnotetext{
${ }^{12}$ M. Anshary MK, Kedudukan Anak Dalam Perspektif Hukum Islam dan Hukum Nasional ..133.

${ }^{13}$ H.R. Abdussalam, Hukum Perlindungan Anak, (Jakarta : PTIK, 2012), 2.
}

menuruti ekspektasi sosial. Maka, kunci menuju integrasi sosial menurut Parsons adalah proses kesalingbersinggungan antara sistem kepribadian, sistem budaya dan sistem sosial, atau dengan kata lain stabilitas sistem. ${ }^{14}$

Merujuk teori diatas adanya stabilitas sistem sudah diakomodir dengan secara yuridis keberadaan anak nikah sirri tersebut tetap mendapat pengakuan, perlindungan dan kepastian hukum yang adil serta perlakuan yang sama dihadapan hukum, sebagaimana ketentuan Pasal 28D ayat (1) UndangUndang Dasar RI Tahun 1945. Tetapi, perlindungan hukum yang diberikan kepadanya tentu berbeda dengan anak sah dari perkawinan yang memenuhi norma hukum, adalah karena kesalahan ibu dan bapaknya yang ketika melaksanakan pernikahan tidak taat kepada hukum yang berlaku. Ketidaksamaan perlindungan hukum yang diberikan negara kepada anak tersebut, seperti hak menuntut warisan dari harta peninggalan bapaknya, oleh karena hubungan hukum antara anak dengan bapak kandungnya tidak didukung oleh bukti yang otentik berupa akta nikah orang tuanya, maka secara formil ia tidak dapat mengajukan gugatan waris melalui lembaga formal yakni lembaga peradilan. Tetapi, dengan merujuk pada teori Talcott Parsons di atas bahwa ia tetap berhak menuntut hak warisnya melalui jalur tidak formil, umpamanya melalui jalur musyawarah keluarag atau desa. $^{15}$

\footnotetext{
${ }^{14}$ George Ritzer - Douglas J. Goodman, ,280-281.

${ }^{15}$ George Ritzer - Douglas J. Goodman , . 144.
} 


\section{KESIMPULAN}

Berdasarkan hasil penelitian yang diuraikan di atas, kesimpulan yang dapat diambil dari penelitian ini adalah sebagai berikut :

1. Sistem pembagian harta bersama yang dilaksanakan oleh rumah tangga TKW yang bercerai dari perkawinan sirri di Desa Bunder menggunaka sistem berikut ; (a) apabila suami lebih banyak bekerja dibanding isteri, menghasilkan harta maka bagian suami sama besar dengan bagian isteri dihitung dari jumlah banyaknya aset dalam keluarga, (b) apabila isteri lebih banyak bekerja dibanding suami, menghasilkan harta maka bagian isteri lebih besar dibanding bagiannya suami dihitung dari jumlah banyaknya aset dalam keluarga, dan (c) apabila suami atau isteri bekerja mengahasilkan harta yang sama banyaknya maka bagian isteri lebih besar dibanding bagian suami.

2. Adapun kedudukan anak dari perkawinan sirri secara yuridis keberadaan anak nikah sirri tersebut tetap mendapat pengakuan, perlindungan dan kepastian hukum yang adil serta perlakuan yang sama dihadapan hukum, sebagaimana ketentuan Pasal 28D ayat (1) UndangUndang Dasar RI Tahun 1945

\section{DAFTAR PUSTAKA}

\section{Buku}

Abdussalam R. (2012), Hukum Perlindungan Anak. Jakarta : PTIK.

Arikunto Suharsimi. (2005). Manajemen Penelitian. Jakarta: Rineka Citra.
Mardani. (2011). Hukum Perkawinan Islam di Dunia Islam Modern. Yogjakarta: Graha Ilmu.

MK M. Anshary. (2014). Kedudukan Anak Dalam Perspektif Hukum Islam dan Hukum Nasional. Bandung : CV Mandar Maju.

Muhammad Abdulkdir. (2004). Hukum dan Penelitian Hukum. Bandung: Citra Aditya Bakti.

Ritzer George - Douglas J. Goodman. (2011). Teori Sosiologi Modern. Jakarta: Kencana Prenada Media Group. Edisi Ke-6.

Soerjono Soekanto. (2010). Pengantar Penelitian Hukum, Jakarta: UI Press.

Sri Sutanti Indriyani. (2007). Sosiologi Suatu Kajian Hidup Bermasyarakat. Sukoharjo: Ghalia Indonesia.

Wahyono Darmabrata. (2003). Tinjauan UU No. 1 Tahun 1974. Gitama Jaya, Jakarta.

\section{Jurnal}

Jurnal Ilmiah FENOMENA, Volume X, Nomor 2, November 2012: 982-998.

\section{Peraturan Perundang-undangan}

Undang-Undang Dasar RI Tahun 1945

Undang-Undang Nomor 1 Tahun 1974 tentang Perkawinan

Kompilasi Hukum Islam (KHI)

$\begin{array}{cr}\text { Keputusan Fatwa Majelis Ulama } \\ \text { Indonesia Nomor: 4/MUNAS } \\ \text { VII/MUI/8/2005 } & \text { tentang } \\ \text { Perkawinan Beda Agama. } & \end{array}$

